\title{
An Assessment of the Challenges Facing Implementation of Guidance and Counselling Programme in Public Secondary Schools: A Case of Lugari Subcounty, Kakamega County, Kenya
}

\author{
Rebecca Amambia Magero \\ Principal Ratanga Girls High School, Homa Bay County \\ Nephat J. Kathuri \\ Kenya Methodist University \\ Bernard Wamalwa \\ Kenya Methodist University
}

\begin{abstract}
Students studying in public secondary schools in Kakamega County, Lugari Sub-County have a range of challenges, which include, deteriorating academic performance, drug and substance abuse, low self-esteem and socially unacceptable behaviour such as destruction of school property, among others. These problems exist despite the fact that guidance and counselling programmes were established in Kenyan public Secondary Schools in 1970s. This study carried out an assessment on the challenges facing implementation of guidance and counselling programme in public Secondary Schools in Lugari Sub-County. The study employed descriptive survey research design. The target population was 21 principals, 42 Guidance and Counselling teachers, as well as, 336 teachers in public Secondary Schools in Lugari Sub-County, making a total of 399 subjects. The sample size was composed of $30 \%$ of the total target population which was 120 subjects. The 120 subjects were comprised of 6 principals, 12 guidance and counselling teachers and 102 public secondary school teachers from the study area. A pilot study was carried out on the instruments in two Secondary Schools using test/retest method, with a two weeks' interval between the tests, to enable assessment of both validity and reliability of the data collection instruments. Simple random sampling was used to select $30 \%$ of the principals. However, purposeful sampling was used to select the $30 \%$ of the guidance and counselling teachers. Simple random sampling, purposeful, as well as, stratified random sampling were used to select teachers from the schools where the principals were drawn. Stratified sampling was necessary because teachers were selected with respect to their populations in the respective six schools. Data was analyzed using descriptive statistics. Results were presented, using frequency distributions, percentages and narratives for qualitative results. The study established that principals' support to the G\&C departments was minimal as principals gave less weight to the departments. It was also observed that schools had G\&C departments but most lacked teachers with G\&C skills. The study recommends that: school principals should provide $\mathrm{G} \& \mathrm{C}$ teachers maximum support so as to ensure that discipline is maintained through counselling in the secondary schools. Teachers should take in-service courses and short seminars in G\&C, especially those who had not received formal training in G\&C.
\end{abstract}

Keywords: Guidance and counselling, principals' support, guidance and counselling teachers' qualifications and training.

DOI: $10.7176 / \mathrm{JEP} / 11-32-16$

Publication date: November $30^{\text {th }} 2020$

\section{Background of the Study}

\subsection{Introduction}

Guidance and counselling helps students handle their psychological challenges that can badly impact their studies. Through G\&C, students learn how to peacefully coexist in unity with others in the school community. The gap between students and the school administration is bridged and talks related to alcohol, drugs, personal feelings or any kind of abuse openly discussed. This is because high school G\&C has a considerable role to play in the entire development and growth of students in high schools, such as, discipline among the students, having a positive attitude towards life and managing stress, among learners. The students in high school level are at adolescent stage which is signaled by changes in both their psychological and physical being, such as, need for independence from grown-ups, ease in accepting peer pressure, attachment of value to romance and sexual relationships, with some becoming defiant. Mutie and Ndambuki (1999) stipulate that these changes present challenges in their education, social and personal self. Hence, school counsellors are essential members within the education team.

Training of school counsellors within the US system is directed by an accredited council of councilors and a programme of education related to it that has standards. (ASCA, 2012). In Kenya, the curriculum is grounded on counsellors who focus on the community or models of private practice that have little regard for existential learning 
or distinctive needs of a school set up. Programmes targeting school counsellors is constituted by analyzing curricula of other countries, then modifying them to suit the requirements of schools in Kenya. Theory and existential training should be included in the school counsellor's curriculum. While on training G\&C teachers need suitable internship and apprenticeship will need organized supervision from the supervisor in the field and the instructor within the university. According to Romano \& Wahl (2005), this can only be attained when the university collaborates with the schools.

In addition, issues of ethics can be considered through re-evaluating present tutoring of school counsellors. There is need therefore, for crafting of ethical standards distinct to counselling in schools. Teaching of these standards should be done to trainee counsellors to impart them with the concepts of deciphering ethical challenges that they will be confronted with while in school. Gysbers \& Henderson (2012) state that an extensive guidance and counselling programme will need to be operationalized in Kenya that addresses school counsellors for their functions and roles to be defined successfully.

On top of that it is essential for the G\&C teachers to gain broad knowledge by attending workshops and lectures, internship and apprenticeship while in practice in order to update their practical responsibilities and duties.

Even though guidance and counselling in Africa is still a new concept within systems of education, it has been welcomed by majority of the nations (UNESCO, 2001). Significant successes have been reported in establishing administrative structures so as to provide services focusing on guidance and counselling within institutions of learning to enhance the development of students on a vocational, educational and personal level.

The education system in Africa did not emphasize on guidance and counselling until when respective countries got independence since, it was presumed that guidance and counselling was something to be offered by parents at home, within the community or even within religious settings by the religious leaders and other religious persons (Mutie \& Ndambuki, 1999).

In Tanzania, learning institutions officially implemented guidance and counselling in 1970 with the aim of assisting learners cope with social, vocational, educational, psychological and emotional challenges that were part of their everyday lives (Wango \& Mungai, 2007). In order to make it effective, strong and enhance it, services offered by guidance and counselling programmes were expanded through resources provision as recommended by a report produced by a committee whose mandate was to look at the objectives of education policies in the country. Eyo et al. (2010) opined that programmes in secondary schools relating to guidance and counselling must be structured towards focusing on academic challenges of students in adolescent stage, future vocations, social matters, emotional development and physical growth.

In Kenya, the Ministry of Education (MoE) introduced G\&C as a unit in the division of inspectorate in 1970s. According to the Ministry of Education, Science and Technology, the responsibility of the unit was to provide G\&C services to colleges that were training teachers and in-service training to secondary and primary school teachers. In order to deliver high standards of education and training, MoEST (2005) set out to develop a policy addressing $\mathrm{G} \& \mathrm{C}$ within the sector of education, provide $\mathrm{G} \& \mathrm{C}$ services and monitor, as well as, evaluate the $\mathrm{G} \& \mathrm{C}$ programme. The objective of this was to institutionalize and reinforce guidance and counselling within institutions of learning. This ingenuity was nonetheless not supported as it should; consequently, it was not fulfilled, as well, and as efficiently as intended.

A renewed call to develop G\&C within schools in Kenya was further made with a lot of vigour in the 1980's and 1990's in a follow up to the nation experiencing the worst school arson incidents to ever occur. Teenage school girls were raped by male students and 19 others died in a night of dormitory attack in St. Kizito Boarding School in eastern Kenya (The New York Times Archives, July 29, 1991 section A, page 1). In 1998 March, the death of another 26 girls occurred in an arson case meted on Bombolulu girl's secondary school. Other arson attacks occurred in 1999 taking the lives of another 17 girls, while 70 others were raped in a Chepalungu Boarding School. Kyanguli boarding school lost 67 school boys in 2001 in another school arson case meted to them by fellow students while asleep (East African Standard, 2001). The highlighted cases and other incidences caught the government's attention together with other stakeholders in the sector of education.

There is recognition that G\&C programmes were formed to cater for an all rounded growth of needs of learners (UNESCO, 2002). However, Schools in Kenya are yet to observe this. The fact that social, economic and cultural development of learners bases their roots on G\&C is without doubt that Kenya's G\&C has developed with a focus on addressing the discipline need to solve school problems (Ajowi \& Simatwa, 2010).

Despite the knowledge that guidance and counselling contributes to the control of indiscipline in schools; and the expected commitment of the Ministry of Education to establish a secondary school G\&C, many schools in the country continue to experience disciplinary problems. Lugari Boys High School, one of the schools in Lugari Sub County illustrates this trend in Table 1. 
Table 1

Trend of Students Disciplinary Cases in Public Secondary Schools in Lugari Sub County between 2014-2017

\begin{tabular}{lllll}
\hline Type of Indiscipline & 2014 & 2015 & 2016 & 2017 \\
\hline Students' Unrest & 5 & 7 & 28 & 16 \\
Pregnancies & 130 & 256 & 319 & 705 \\
Drug Abuse & 70 & 101 & 213 & 384 \\
\hline
\end{tabular}

The information shown in Table 1 casts doubt on the effectiveness of implementation of guidance and counselling programmes in public secondary schools in Kenya and in Lugari Sub-County, in particular, hence, a call for a study to establish the challenges facing effective implementation of G\&C in secondary schools, with specific focus on Lugari Sub County. The questions that need answers are: Do these schools have functional guidance and counselling departments? If they do, why are there many disciplinary problems?

\subsection{Statement of the Problem}

The Government of Kenya has been coming up with ways of strengthening G\&C programme in its secondary schools after realizing its importance. Despite the government effort, public secondary schools in Lugari Subcounty continue to experience school disruptions due to students' unrest, early pregnancies, drug and substance abuse, among other school malpractices (Table 1). These are clear indicators of inefficiency in G\&C in the Sub County. It is this prevailing situation that calls for a study to establish the challenges facing effective implementation of G\&C in secondary schools, with a specific focus on Lugari Sub County.

\subsection{Objectives of the Study}

The study aimed at achieving the following objectives which suggests the possible causes of the ineffectiveness of the implementation of G\&C programme in the schools;

i. To assess the extent to which the principals' support affect the implementation of guidance and counselling programme in public secondary schools in Lugari Sub-County, Kakamega County.

ii. To investigate the contribution of teacher counsellor training on the implementation of guidance and counselling programme in public secondary schools in Lugari Sub- County, Kakamega County.

\subsection{Significance of the Study}

The findings of the study may contribute to the advancement of knowledge about guidance and counselling in Kenya. It is therefore, anticipated that the outcome of the study may benefit the Kenya Institute of Curriculum Development in reviewing the G\&C curriculum. School administrators, comprising of the principal and deputies will understand why the programme is not working effectively and hence, support the G\&C teachers in achieving G\&C roles. The Ministry of Education will learn about teacher's workload and counsellors' personality and hence, address it in G\&C courses provided for teachers. Consequently, this report will assist all the stakeholders in making the necessary adjustments to make implementation of the G\&C programme in schools more effective.

\section{Review of Related Literature}

Guidance and counselling involves giving directions to a learner to carry out a required task that is meant to mould his or her character. It also includes assisting a student or any other person to resolve his or her academic, psychological and social challenges facing him or her.

The roles of principals in the school administration are clearly laid down. Among others, the principals are adopters of the school policies and procedures as provided by the state. They provide leadership within the team which include managers and trained educators as they provide and effectively utilize resources which include human, financial and material resources (Onyango, 2001). School principals allocate available resources related to school programmes and ensure that these materials are available at all times to ensure that school programmes are not affected. Lastly, they ensure that implementation of G\&C programmes is adhered to. As such, establishing a positive working interrelationship between the school counsellor and the principal is vital to the success of the counsellors (Mwaniki, 2008).

Some principals are not sure about the counsellor's roles and duties in the school. This is because the latter lack knowledge of the formers' roles and duties. The counsellors are looked upon with a lot of suspicion by the principals. The reason for this is because the counsellors tend to be too close to the students. They are supposed to handle the students' issues with confidentiality. So, when information is kept from the principal and he/she gets suspicious, conflicts are sure to arise between the principal and the teacher counsellor (Mwaniki, 2008).

Counsellors extend their prospects of successful cooperation when they view their professional input is cherished. When they learn that principals cherish their input, counsellors may feel appreciated by the administrators and deliver more usefully to their learners and educators. The teacher-counsellor's efficiency will be increased once they learn that the managers cherish their professional input. This further increases the level of job satisfaction experienced by the counsellors (Kimathi, 2002). Kimathi (2002), in her study on perception of the 
teachers' role, acknowledged that in as much as the principal or teacher counsellor may be committed and competent, they cannot attain an effective programme implementation without the co-operation of other people. Wanjohi (1990), in his study observed that when the principal supports the teacher counsellor, there will be a better reaction from the learners on the provided services. Williams (1993) agreed by adding that when the principal withholds support from the programme, little commitment and devotion will be provided to the learners by the teachers.

In Lugari Sub County principals play a lesser role than expected in ensuring guidance and counselling programmes are managed in the schools. There is negligence on matters regarding guiding and counselling as resources such as finances and materials are not provided to the department.

Principals are required to avail resources for programmes related to guidance and counselling. Unavailability of support and resources may develop considerable challenges for school counsellors operating in Kenya. Apparently, school counsellors have raised the issue of school principals not providing the needed support. When the $\mathrm{G} \& \mathrm{C}$ teachers perform their duties in isolation, they will not succeed in the responsibilities as school counsellors. Regrettably, few counselling units exist in Kenyan secondary schools and where they do, they are poorly supplied with the required resources or the unit is not suitably located. There is sharing of offices in some institutions between the teaching staff and the school counsellors, hence compromising individual records of students, which are deemed confidential. It was noted by Mushaandja et al. (2013) that teachers and school administrators are not providing the adequately needed support by school counsellors. This is caused by inadequate information concerning counselling to enlighten school administrator and teachers. It was revealed by Nyamwange et al. (2012) that school counsellors receive minimal support from heads of schools.

Herman (1967) through the American School Counsellor Association conducted a study on various groups and established that school counsellors are required to have expertise in interpersonal working relationships and self-acceptance. The same study concluded that the school counsellor should have essential competence in behavioural sciences. According to the study, the most vital matter that affects counselling, is quality of preparation of the counsellor and assurances of expertise needed by teacher counsellors. The concept of a teacher counsellor as viewed by Milner (1974), suggests that counselling is offered by an individual who should have had received relevant capacity building, although there are a few people who can counsel without training. This reflects, to some extent, the concept of teacher counsellors' practices in Kenyan secondary schools. In this context, any individual in the setup of a school, just by expressing their interest in assisting learners is guided to be able to provide G\&C services, for instance, the chaplain of the school, its teaching staff and the administrators. This is a negative perception because just like any other profession, counselling needs practical expertise and theories to carry out, hence, the need for training (Pecku, 1991).

In their studies, Mutie \& Ndambuki (1999) tend to disagree with the foregoing view of teacher counsellor in Kenyan secondary schools and emphasizes that in getting ready for counselling, it is essential that the teacher should be equipped with experience on psychotherapy and personality theories and also approaches to behavioural interventions and diagnosis, including the aspects of human behaviour. Every counsellor should be prepared to be challenged to perform in accordance with their full capabilities. It is noted by the GoK (1978) that its development strategy of 1979-1983 was to incorporate guidance and counselling into the curriculum of teacher training within university and college levels. According to Tumuti (2002), even though this suggestion was then applied, the course of guidance and counselling was not productively addressed and the course only focused on the introductory part of guidance and counselling. This left educators with very little in terms of guidance and counselling. The teachers were, therefore, left incapacitated to deliver the much-needed service.

In a study by Nthusi (1999), which focused on how secondary schools were selecting teacher counsellors, it was observed that in Kenya, teacher counsellors were at times nominated by the school heads, elected by teachers or proposed to head the unit by the Teachers' Service Commission (TSC). There was no consideration as to whether the teacher possessed appropriate expertise and experience in guidance and counselling. The teachers providing $\mathrm{G} \& \mathrm{C}$ were, therefore, ineffective because they possessed little understanding for their responsibilities in G\&C, leave alone the suitable practical skills. (Kamunge, 1988; MoEST, 2005). The focus of training is to be able to succeed in acquiring positive attitude and the required knowledge during guidance and counselling programme. Nonetheless, Mapfumo and Nkoma (2013) note that majority of nations in sub-Saharan Africa are acutely faced by inadequate numbers of trained teacher counsellors. Inadequacy of trained staff was one of the items mentioned as an obstacle faced by teacher counsellors.

Mapfumo and Nkoma (2013) in their study evaluated the readiness and expertise of staff conducting guidance and counselling in secondary schools. The study revealed that just a single principal was qualified to provide guidance and counselling services. According to Mapfumo (2001), the teachers who were tasked with providing school guidance and counselling were qualified teachers but lacked the prerequisite training in guidance and counselling and therefore, did not have the required training to effectively provide guidance and counselling.

In many cases, the assignment to G\&C is not based on G\&C training requirements. In Lugari Sub County, schools are facing shortage in guidance and counselling departments, since the Teachers Service Commission has 
not succeeded in posting teachers with G\&C skills in the learning institutions within the Sub County (Ngumi, 2003). School principals have been constrained in providing time and resources to existing teachers for short courses in guidance and counselling as recommended by MoEST (2000). This limitation among school principals has made guidance and counselling departments ineffective. In Lugari Sub County there is limited consideration as to whether the educators hold prerequisite expertise and experience in G\&C for him/her to offer services of guidance and counselling.

\section{Theoretical Framework}

This study was anchored on social exchange theory. Social exchange theory is a distinguished conceptual frame of reference that has been predominantly applied in social psychology and sociology. The theory is traced to Emerson (1976) who tries to illuminate on social dynamics and stability as proceedings that include negotiating exchanges between parties. According to the theory, all relationships by human beings are established through an impressionistic cost and benefit evaluation and considerations of alternatives. Case in point is a person who believes that the cost of a relationship would exceed the assessed benefits would decide to pull out of the relationship. The guidance and counselling programme in the school is constituted of the teacher counsellor, students and the principal. The theory was relevant to this study as it assessed the challenges facing implementation of guidance and counselling programme in public secondary schools. The relationship in this case is the support the principal provides to the G\&C programme in terms of the personnel, infrastructure, finances and time provided to the teacher counsellor. The teacher counsellors also appreciate the support by giving their all to the $\mathrm{G \& C}$ programme. The students on the other hand will appreciate the time and considerations being put in place to stir them to the best directions. The students would only seek counselling services if they think something useful will come out of it. Without a perception of value addition, the students will keep away. The teacher counsellors would also devote their time to providing counselling services if they expect a positive outcome from the process. They would otherwise stay away if they are demotivated and demoralized. The G\&C programme, therefore, entails social relationships and exchanges among the teachers, teacher counsellors and the school principals. An effective social exchange among the players will lead to effective school G\&C programme.

The social exchange can only be effective if the principals' support and teacher counsellor's appropriate training are appropriate for the implementation of the programme.

Consequent to the literature reviewed and the theoretical framework, the independent variables and respective indicators were identified as;

a) Principals' support whose indicators were, teamwork, his trust for G\&C, working relationship with the $\mathrm{G} \& \mathrm{C}$ teacher, as well as, the resources allocation.

b) Teacher counsellor's training whose indicators were management of G\&C by senior school managers, qualifications of the G\&C teacher, his/her practical skills, information on G\&C roles, as well as, quality of training in G\&C.

The dependent variable for the study was the effectiveness of the G\&C programme implementation as reflected by decrease in antisocial behaviour, improved teacher-student relationship, improved school discipline and improved academic performance.

\section{Research Methodology}

The study was carried out in Kakamega County which has 12 sub counties which includes Lugari Sub County. Lugari Sub-County was chosen because of its high number of indiscipline cases among students in public secondary schools within the sub county in comparison with the rest of the sub counties within the county, hence, putting to question the effectiveness of the implementation of $\mathrm{G} \& \mathrm{C}$ programme within public secondary schools in the sub-county.

The study employed a descriptive survey research design. The researcher selected this design since interviews and questionnaires were to be used for acquiring pertinent information on participant's lifestyle, behaviour, feelings, and attitude. The design also enabled the researcher to acquire and analyse information from a wide range of respondents in Lugari Sub County, that is; the principals and teacher counsellors.

The study targeted a population of 21 Principals, 42 teacher counsellors and 336 teachers, making a total target population of 399 participants (Table 2). Principals were to be involved in the study so as to help obtain data on the variable, principal's support on G\&C, Teacher counsellors and teachers were best positioned to provide information on teacher counsellor training.

The researcher adopted the Mugenda and Mugenda (2009) recommendation of a sample size of 10-30\% of the target population. Results from such a sample size are acceptable and reflective of the outcome of the target population. Using $30 \%$ of the recommendation, the sample size consisted of 6 principals, 12 teacher counsellors and 102 teachers, making a sample size of 120 respondents (Table 2). Random sampling was used to select the 6 principals. The 12 teacher counsellors were purposefully selected from the six schools where the principals were selected. The 102 teachers were purposively selected from the six schools. Proportionate random sampling was 
used to ensure equal and proportionate representation of the teachers.

Table 2:

Sample Size in Relation to Target Population

\begin{tabular}{lcc} 
Stratum & Target Population & Sample Size \\
\hline Principals & 21 & 6 \\
Teacher Counsellors & 42 & 12 \\
Other teachers & 336 & 102 \\
\hline Total & $\mathbf{3 9 9}$ & $\mathbf{1 2 0}$ \\
\hline
\end{tabular}

Interview guides and questionnaires were used as tools for data collection. Questionnaires were used to solicit data from the teacher counsellors and other teachers, since they were relatively many in number. In addition, questionnaires are appropriate for gathering detailed data within a short period of time. Interviews were used on school principals as they were relatively few in number. Interviewing was, therefore, used to obtain first-hand information from the top leadership of schools.

The researcher conducted piloting within two randomly selected public secondary schools in a sub-county next to Lugari Sub-County that had similar characteristics as the study area. Six teachers, two G\&C teachers and two principals were selected for the study. The purpose for piloting was to help the researcher to check the clarity of the items, get the responses and establish how well the questions would be answered. It also helped in provoking comments from the respondents that would help in the improvement of the instrument's comprehension. The questions that were left blank or inappropriately answered in a way the researcher was not expecting, were modified, accordingly. Generally, piloting assisted the researcher to discover weaknesses in the research instruments so that they could be modified beforehand. This ensured that the data collection instruments were valid.

The outcome of the piloting assisted in ascertaining the lucidity of the items and the duration taken to administer the instruments. Experts were also consulted for further validation, in addition to ensuring that the items were comprehensive enough for the respondents. The researcher ensured that all the items were extracted from the research objectives.

To test reliability, test re-test reliability approach was adopted to approximate the level at which the outcome could be acquired when repeated using similar concepts. The scores from the two administrations were correlated with each other using Pearson's product moment formula, in order to establish the extent of reliability. Reliability coefficient of 0.76 was obtained. This reliability coefficient was considered acceptable since the minimum coefficient in social sciences is 0.70 . The questionnaire items were, therefore, considered fit enough for the main data collection. The interview schedule items were assessed by equating responses from various respondents. All the preceding procedures ensured that the data collection instruments were valid and reliable.

Prior to embarking on field work, the researchers requested for an introduction letter from Kenya Methodist University which was the University of affiliation. The letter's main purpose was to facilitate being granted a permit to conduct research in Kenya by the Kenya National Commission for Science, Technology and Innovations (NACOSTI). After this, the researchers visited the schools concerned, prior to the day of administering data collection instruments, for familiarization with the school administration, as well as, guidance and counselling heads. During this visit, appointments were made as to when the administration of the instruments could be conducted. Questionnaires were hand delivered to teacher counsellors and teachers by the researcher and the subjects were given 30 minutes for completion of the questionnaire. Interviewing was conducted within a period of three days in which a maximum of 20 minutes were given per interviewee. Interview time was extended in case it was necessary, so as, to obtain critical information.

The collected data was scrutinized to detect whether there were any errors or any omissions. The coded data was tabulated, and then evaluated descriptively and thematically. Quantitative analysis involved coding of data. The data was also categorized according to the responses with respect to the set objectives. The analysis was facilitated by use of SPSS computer software. Qualitative data was also categorized into themes derived from the data. Various categories were then coded and explored through the SPSS version 22.0 computer software. Results were presented using frequency tables and narratives.

Ethical considerations were observed in this survey through guaranteeing confidentiality of information and of respondents, treating respondents with due regard and nobility, as well as, maintaining high standards and procedures throughout the process. The respondent's accord was sought at the beginning of the study for them to take part, as well as, agreeing to use of the acquired data, its evaluation and eventual reporting and dissemination. The confidentiality and privacy of the participants were treated in high regard and at no point were they required to provide their names or any form of information that uniquely identified them within the questionnaire. Data analysis was not conducted on an individual participant basis but collectively as a pool of responses. 


\section{Results and Discussion \\ 5.1 Introduction}

The purpose of this study was to identify challenges facing implementation of guidance and counselling programme in public secondary schools of Kenya, with particular reference to Lugari Sub-County, Kakamega County. In order to achieve this purpose, the following objectives were addressed.

i. To assess the extent to which the principals' support affect the implementation of guidance and counselling programme in public secondary schools in Lugari Sub-County, Kakamega County.

ii. To investigate the contribution of teacher counsellor training on the implementation of guidance and counselling programme in public secondary schools in Lugari Sub- County, Kakamega County.

Out of 120 subjects a total of 106 subjects responded during data collection process. The responses by various categories of respondents and the overall response rate are outlined in Table 3.

Table 3:

Response Rate

\begin{tabular}{lccc}
\hline Category & Sample & Response & Response rate \\
\hline Principal & 6 & 6 & 100 \\
Guidance and Counselling teachers & 12 & 12 & 100 \\
Teachers & 102 & 88 & 86.3 \\
\hline Total & $\mathbf{1 2 0}$ & $\mathbf{1 0 6}$ & $\mathbf{8 8 . 3}$ \\
\hline
\end{tabular}

The rate at which the questionnaires were returned was regarded to be adequate and acceptable in making reasonable inferences. According to Mugenda and Mugenda (2009) a 75\% response rate or more is both credible and acceptable. The response rate in this study was therefore, considered excellent and suitable for further analysis and generalization.

\subsection{Challenges Facing Implementation of the Guidance and Counselling Programme with Respect to the Principals Support}

As observed earlier (Mwaniki, 2008), the support of the school principals is quite essential for development, application and maintenance of guidance and counselling programmes, as well as, the success of teacher counsellors implementation of $\mathrm{G} \& \mathrm{C}$ programmes. Consequently, establishing a positive working relationship between principal's and the school counsellors is vital to the success of the teacher counsellors.

Five indicators of support were explored, as outlined on Table 4. The responses of both teacher counsellors and other teachers are as per Table 4.

Table 4:

Influence of Principals Support on Implementation of the Guidance and Counselling Programme

\begin{tabular}{|c|c|c|c|c|c|c|}
\hline Statements & SD & D & $\mathbf{N}$ & A & SA & Totals \\
\hline $\begin{array}{l}\text { Team work in Guidance and } \\
\text { Counselling }\end{array}$ & $8(8 \%)$ & $12(12 \%)$ & $8(8 \%)$ & $32(32 \%)$ & $40(40 \%)$ & $100(100 \%)$ \\
\hline $\begin{array}{l}\text { Strong influence on school's counsellor } \\
\text { programmes }\end{array}$ & $12(12 \%)$ & $8(8 \%)$ & $20(20 \%)$ & $28(28 \%)$ & $32(32 \%)$ & $100(100 \%)$ \\
\hline Good working relationship & $10(10 \%)$ & $12(12 \%)$ & $4(4 \%)$ & $20(20 \%)$ & $40(40 \%)$ & $100(100 \%)$ \\
\hline $\begin{array}{l}\text { More time in Guidance and } \\
\text { Counselling }\end{array}$ & $32(32 \%)$ & $28(28 \%)$ & $20(20 \%)$ & $10(10 \%)$ & $10(10 \%)$ & $100(100 \%)$ \\
\hline $\begin{array}{l}\text { Trust among teacher counsellors by } \\
\text { principals }\end{array}$ & $20(20 \%)$ & $8(8 \%)$ & $12(12 \%)$ & $20(20 \%)$ & $40(40 \%)$ & $100(100 \%)$ \\
\hline
\end{tabular}

Table 4 shows responses on the Influence of principals' support on implementation of guidance and counselling programme. Seventy two percent of the respondents either agreed or strongly agreed that school principals provided support to teachers on guidance and counselling programme through team work in G\&C. This was a positive response which was in line with the Ministry of Education (1977), which asserted that the success of guidance and counselling programmes rely on developing better relations between principals and teacher counsellors. Sixty percent of the respondents either agreed or strongly agreed that there was a strong influence on schools' counsellor programmes. Regarding a good working relationship between principals and guidance and counselling department, $60 \%$ of the respondents agreed or strongly agreed. This was the same case regarding the principals' trust on teacher counsellors. However, of the respondents, $60 \%$ either disagreed or strongly disagreed that there was adequate time allocated for guidance and counselling in their schools. However, it needs to be observed that concerning the allocation of adequate time for guidance and counselling, $60 \%$ responded on the negative, while $20 \%$ indicated that the time allocated was adequate. An attempt to work out the overall mean rating indicated that $30 \%$ disagreed or strongly disagreed that there was adequate support, while $55 \%$ agreed or strongly agreed. However, except for the fourth indicator, adequacy of time allocated for guidance and counselling, the respondents expressed their satisfaction with the principals' support. That satisfaction with teamwork, influence of the school counsellor programmes, good working relationship and principals' trust on the teacher counsellors 
was of little value if there was inadequate time to implement the schools G\&C programme. It seems that many principals did not recognize the need for allocating reasonably adequate extra time for the programme implementation. No wonder more often than not, the counsellors found themselves being assigned other tasks in the schools, which left them with too little time for the students. This is because; they were required to carry out other non-counselling duties which diminished the overall commitment to the counselling programme, which subsequently reduced their effectiveness. Dissatisfaction was well expressed by one of the teacher counsellors, who during an informal interview stated that,

"I find it difficult to run the guidance and counselling department. My principal is not cooperative and he has sidelined my department on what he calls concentrating on academic oriented sectors, forgetting that education without character is useless".

During an interview with school principals, most of them indicated that they focused mostly on academic and co-curricular activities. One of them stated that;

"'A school has many aspects of learning and all of them need money. Outcomes of academic programmes are closely monitored by different stakeholders and reward or punishment is given by the end of the year. I would rather spend money to run programmes that will earn me a name than invest in $G \& C$ which is not examinable,"

This implies that some principals were rigid in embracing support for guidance and counselling. Among the criteria investigated, the greatest challenge was principal's support in form of provision of adequate time.

\subsection{Training of Teacher Counsellors as a Challenge to the Implementation of Guidance and Counselling Programme}

A school counsellor should have personal competence in self-acceptance and interpersonal working relationships. Equally the counsellor should have essential components in behavioural sciences (Herman, 1967). According to Herman, the most critical issue that faces counselling is the quality of counsellor preparation and guarantee of competence in the roles they must fulfill. Milner (1974) stresses that counselling should be provided by a person who is expected to have had some training for this work, although there are a few people who can counsel without training. In their study, Ndambuki \& Mutie (1999) disagreed with the above view and emphasized that in getting ready for a session in counselling, it is essential to possess experience on psychotherapy and theories of personality. Preparation of G\&C teachers should also include training in behaviour mediation approaches and analysis, including changing aspects of human behaviour. According to RoK (2001) universities and colleges were to incorporate a unit on $\mathrm{G} \& \mathrm{C}$ in the curriculum while training teachers. In order to investigate whether there was any challenge to the implementation of the G\&C programme, five indicators were selected as outlined in Table 5. The indicators included: management of $\mathrm{G} \& \mathrm{C}$ by senior teachers and principals understanding of personality, psychotherapy and behaviour interventions, techniques, familiarity with roles of G\&C, as well as, appointment of teacher counsellors based on appropriate qualifications. The responses are outlined on Table 5.

The table shows teachers' responses on whether there was influence of counsellor training on the application of the guidance and counselling implementation. According to Table 5, 92\% either strongly disagreed or disagreed that schools had quality teacher counsellors. This strong rejection that schools lacked quality counsellor teachers, was surprising as principals, deputies or senior teachers manage G\&C, as per Kamunge report (1988). Furthermore, $88 \%$ either strongly disagreed or disagreed that use of practical skills in G\&C was practiced by stakeholders. As to whether teacher counsellors understood theories of personality, psychotherapy and behavioural intervention techniques, $88 \%$, either disagreed or strongly disagreed. Fifty two percent either strongly disagreed or disagreed that they were conversant with roles in guidance and counselling as $92 \%$ either strongly disagreed or disagreed that appointment of teacher counsellors was based on qualifications in G\&C. The overall rating was that $82 \%$ either strongly disagreed or disagreed. This was an indication that there was a dire need for the training of G\&C teachers, as well as, in the management of the G\&C programmes in schools. From interviews, it emerged that some schools were yet to implement the Kamunge report (1988) that stated that either principals or senior teachers be in charge of guidance and counselling. Whether they were in charge or not, they lacked skills in the area of guidance and counselling. Furthermore, dual roles of school leadership, as well as, being in charge of G\&C department was unrealistic. One of the principals also affirmed that,

"My guidance and counselling teacher lacks skills in $G \& C$ despite requesting for a competent one from the Ministry of Education, this has left a deficit in G\&C department which has led to unruly behaviour in my school". 
Table 5:

Influence of Counsellor Training on Implementation of Guidance and Counselling Programme

\begin{tabular}{|c|c|c|c|c|c|c|}
\hline Statements & SD & D & $\mathbf{N}$ & A & SA & Totals \\
\hline $\begin{array}{l}\text { Principals, deputies or senior teachers } \\
\text { manage } G \& C \text { as per Kamunge report }\end{array}$ & $80(80 \%)$ & $12(12 \%)$ & $0(0 \%)$ & $8(8 \%)$ & $0(0 \%)$ & $100(100 \%)$ \\
\hline $\begin{array}{l}\text { Use of practical skills in Guidance and } \\
\text { Counselling is practiced. }\end{array}$ & $80(80 \%)$ & $8(8 \%)$ & $12(12 \%)$ & $0(0 \%)$ & $0(0 \%)$ & $100(100 \%)$ \\
\hline $\begin{array}{l}\text { Understand theories of personality, } \\
\text { psychotherapy and behavioural } \\
\text { intervention technique }\end{array}$ & $68(68 \%)$ & $20(20 \%)$ & $8(8 \%)$ & $4(4 \%)$ & $0(0 \%)$ & $100(100 \%)$ \\
\hline $\begin{array}{l}\text { Conversant with roles in guidance and } \\
\text { counselling. }\end{array}$ & $32(32 \%)$ & $20(20 \%)$ & $8(8 \%)$ & $8(8 \%)$ & $32(32 \%)$ & $100(100 \%)$ \\
\hline $\begin{array}{l}\text { Appointment of teacher counsellor based } \\
\text { on qualification in G\&C. }\end{array}$ & $68(68 \%)$ & $24(24 \%)$ & $8(8 \%)$ & $0(0 \%)$ & $0(0 \%)$ & $100(100 \%)$ \\
\hline
\end{tabular}

Some of the guidance and counselling teachers lamented about the procedure used in the selection of teachers to undertake guidance and counselling as sometimes it was unsatisfactory. This was also noted by Nthusi (1999) that sometimes skills were not considered in choosing guidance and counselling teachers. One other principal asserted that he found it difficult to handle students' character due to less skills of those assigned the duty. He further asserted that he gave G\&C roles to the school chaplaincy where priests or nuns counselled students. This implies that the Ministry of Education was yet to set out the qualities to be considered when recruiting guidance and counselling teachers and as a result, it has led to unruly behaviour in schools. As a whole, effective training of counsellors remains a big challenge to the implementation of guidance and counselling programmes in Kenyan secondary schools.

In the year 2000 (MoEST, 2000), it was recommended that there should be in-service courses and seminars for all practicing teacher counsellors in secondary schools organized at district levels and coordinated by the guidance unit at KIE (current KICD). The teacher counsellor was expected to gain knowledge and practical skills appropriate for guidance and counselling. However, the preceding results indicate that there was much more that was needed than in-service training and seminars in the preparation of skilled and competent teacher counsellors.

\section{Summary, Conclusions and Recommendations \\ 6.1 Summary of the Findings}

The study established that principal's support to the G\&C department was minimal. An overall mean rating indicated that $30 \%$ of the respondents disagreed or strongly disagreed that there was adequate support, while $55 \%$ agreed or strongly agreed. However, it needs to be noted that except for the adequacy of time allocated for G\&C, the respondents expressed their satisfaction with the principal's support. That satisfaction with teamwork, influence of the school counsellor programmes, good working relationship and principal's trust on the teacher counsellors, was of little value if there was inadequate time allocated to implement the schools G\&C programme. It seems that many principals did not recognize the need for allocating reasonably adequate extra time for the programme implementation.

The study established that schools had guidance and counselling departments but to a great extent, they lacked teachers with G\&C skills. The overall rating indicated that $82 \%$ of the respondents either strongly disagreed or disagreed that G\&C teachers had the appropriate training, skills and experience to appropriately handle G\&C cases. There was, therefore, a dire need for the training of the teachers, as well as, in the management of the programmes in the schools. Most of the teachers handling the department lacked adequacy of the needed skills. In some schools either the principal or the senior teacher was in charge of guidance and counselling, yet they lacked the relevant knowledge and skills.

\subsection{Conclusions}

This study had sought to investigate the challenges facing implementation of guidance and counselling in Lugari Public secondary schools. The conclusions were as follows:

Principals are key in the establishment and maintenance of G\&C departments. Their full participation in running the programme is very critical. Generally, there has been inadequate relevant principal's support, therefore, a big challenge to the effective implementation of the G\&C programme.

Lack of adequate training and experience among those who participate in the implementation of the G\&C in secondary schools is a big challenge to the implementation of the programme. The inadequacy of the training and experiences in $\mathrm{G} \& \mathrm{C}$ contributes to lack of adequate knowledge on the planning and implementation of the $\mathrm{G} \& \mathrm{C}$ programme in secondary schools. 


\subsection{Recommendations}

School principals should provide guidance and counselling teachers maximum support to ensure effectiveness in the teachers' G\&C responsibilities. This eventually yields good fruits through improved school discipline and improved academic performance.

Guidance and counselling teachers should take in-service courses and short seminars in guidance and counselling. Where possible, the principal and the TSC can even release them for further education and training. This will make them skilled and more efficient in guidance and counselling.

\section{References}

Ajowi, J. O. \& Simatwa, E. M. W. (2010). The role of guidance and counselling in promoting discipline in secondary schools in Kenya. Educational Research and Reviews, 5(5), 263-272. http://www.academicjournals.org/ERR

ASCA (2012). The millennium Development Goals, Report 2007. https://www.who.int/pmnch/knowledge/topics/un mdgreport_2007/en/

East African Standard. (2001, April 23). School tragedies related to indiscipline. The East African Standard Media Group.

Emerson, R. M. (1976). Social Exchange Theory. Annual Review of Sociology, 2(1), $335-362$. 10.1146/annurev.so.02.080176.002003

Goldfried, M. R. (1982). Converging Themes in Psychotherapy: Trends in Psychodynamic, Humanistic and Behavioural Practice. Springer.

Government of Kenya (GOK) (1978). The Kenya posts and telecommunications corporation act, chapter 411. Government Printer.

Herman, J. P. (1967). Guidance: A developmental approach ( $\left.2^{\text {nd }} \mathrm{Ed}\right)$. Rand McNally and Company.

Kamunge, I. M. (1988). Report on the Presidential Working Party on Education and Manpower Training for the Next Decade and Beyond. Government Press.

Kimathi, C. K. (2002). Perception of the Teacher Counsellor's Role in the Implementation of Secondary School Curriculum: A case of Central Division, Machakos District [Master's Thesis, Kenyatta University]. Kenyatta University repository. http://ir-library.ku.ac.ke/handle/123456789/2463

Mapfumo, J. \& Nkoma, E. (2013). The State of Guidance and Counselling Programmes in High Schools in Manicaland, Zimbabwe. International Journal of Scientific Research in Education, 6(2), 100-116. https://www.ijlter.org/index.php/ijlter/article/view/593

Mapfumo, J. S. (2001). Guidance and Counselling in Education. Post Graduate Diploma in Education, Module PGDE 012. Zimbabwe Open University.

Milner, P. (1974). Counselling in education. J. M. Dent and Sons Ltd.

Ministry of Education (1977). Educating Our Future Policy. Institutional Supplier Limited. Kenneth Kaunda Foundation.

MoEST. (2000). Kenya education sector support program 2000-2005. http://planipolis.iiep.unesco.org/upload/Kenya/Kenya\%20KESSP\%20FINAL\%202005.pdf

MoEST. (2005). Kenya Education Sector Support Programme 2005-2010. https://www.ircwash.org/resources/kenya-education-sector-support-programme-kessp-2005-2010-strategicplan-development-school

Mugenda O. \& Mugenda A. (2009). Research methods: Quantitative and Qualitative Approaches. Acts Press.

Mushaandja, J., Haihambo, C., Werguani, T. \& Frank, E. (2013). Major challenegs facing teacher counsellors in schools in Namibia. Educational Journal 2(3)77-83

Mutie, E. K. \& Ndambuki, P. (1999). Guidance and counselling for schools and colleges. Oxford University press (E. Africa).

Mwaniki, M. (2008, May 7). Pregnancies kick girls out of school. The Daily Nation. https://www.nation.co.ke/kenya/counties/machakos/over-3900-girls-impregnated-in-machakos-731184

Ng'ang'a, T. (2004, July 31). Counselling week in schools. The Daily Nation. https://www.nation.co.ke/kenya/blogs-opinion/opinion/here-is-how-to-keep-children-from-poor-families-inschool-289624

Ngumi, O. N. (2003). Assessment of the level of training and resource needs of secondary school guidance counsellors in Nakuru Municipality, Kenya [Unpublished Thesis, Egerton University]. Egerton University repository. http://ir-library.egerton.ac.ke/handle/123456789/1186

Nthusi, N. M. (1999). Students' leadership, delinquency guidance and pastoral care in schools. A paper presented on the National conference on student leadership delinquency guidance and pastoral care in schools [Master's thesis, Kenyatta University]. Kenyatta University repository. http://irlibrary.ku.ac.ke/handle/123456789/3952

Nyamwange, C. B., Nyakan, P. O \& .Ondima, P. C. (2012). Assessment of challenges facing secondary school 
guidance and counselling teachers in Nyamira district, Kenya. Journal of Education and Practice, 3(16), 4147. https://www.iiste.org/Journals/index.php/JEP/article/view/3694

Onyango, G. A. (2001). Competencies Needed by Secondary School Headteachers and Implications on PreService Education [PhD Thesis, Kenyatta University]. Kenyatta University repository. https://irlibrary.ku.ac.ke/handle/123456789/2593

Pecku, N. K. (1991). Introduction to guidance for training colleges. Assemblies of God Literature Centre.

Republic of Kenya. (1976). Report of the national committee on education objectives and policies. Nairobi Government Printer.

Republic of Kenya. (2001). Report of the taskforce on students discipline and unrest in secondary schools in Nairobi Kenya. Jomo Kenyatta Foundations.

Tumuti, S. (2002). An introduction to counselling and Psychotherapy. Graduate Manual for Open learning, Kenyatta University.

UNESCO (2001). Module 8: Guidance and Counselling Programme Development. Botswana

UNESCO (2002). The first international conference on guidance, counselling and youth development in Africa, Nairobi, Kenya. http://www.unesco.org/education/news-en/kenya.doc

Wango, G. \& Mungai, E. (2007). Counselling in the School: A Handbook for the Teacher. Phoenix Education. Wanjohi, M. (1990). Distance education: A systems view. Wadsworth.

Williams, K. (1993). The school counsellor. McCheven and Company Ltd. 